\title{
Improved Learning Outcomes of Natural Science Lessons Through Problem Based Learning (PBL) Model Assisted By Power Point Media
}

\section{Desi Nurziammah}

SD Negeri 2 Pabuwaran

desinurziammah@gmail.com

\section{Article History}

received $3 / 12 / 2020$

\begin{abstract}
The purpose of this study is to improve the learning outcomes of students in science mupel in grade $V$ elementary schools with a power point-assisted Problem Based Learning (PBL) learning model. The research conducted is Class Action Research (PTK) as many as two cycles, with each cycle consisting of two meetings. The stages of each cycle are planning, implementation, observation and reflection. Each meeting is conducted pre test and post test to know the development of students. In cycle I students who completed after carrying out the post test by $82 \%$. In cycle II students completed after carrying out post tests by $93 \%$. These results show that the Problem Based Learning (PBL) learning model can improve the learning outcomes of students, especially the Grade V science teacher at SDN 2 Pabuwaran.
\end{abstract}

Keywords: learning outcomes, problem based learning, science

\section{Abstrak}

Tujuan dari penelitian ini adalah untuk meningkatkan hasil belajar peserta didik pada mupel IPA di sekolah dasar kelas $\mathrm{V}$ dengan model pembelajaran Problem Based Learning (PBL) berbantuan power point. Penelitian yang dilakukan adalah Penelitian Tindakan Kelas (PTK) sebanyak dua siklus, dengan setiap siklusnya terdiri dari dua pertemuan. Tahapan setiap siklusnya adalah perencanaan, pelaksanaan, observasi dan refleksi. Setiap pertemuan dilakukan pre test dan post test untuk mengetahui perkembangan peserta didik. Pada siklus I peserta didik yang tuntas setelah melaksanakan post test sebesar $82 \%$. Pada siklus II peserta didik yang tuntas setelah melaksanakan post test sebesar $93 \%$. Hasil ini menunjukan bahwa model pembelajaran Problem Based Learning (PBL) dapat meningkatkan hasil belajar peserta didik khususnya mupel IPA Kelas V di SDN 2 Pabuwaran

Kata kunci: hasil belajar, problem based learning, IPA 


\section{PENDAHULUAN}

Pendidikan adalah proses di mana setiap orang memperoleh pengetahuan, wawasan, dan mengembangkan sikap dan keterampilan. Pendidikan merupakan salah satu aspek penting dalam pengembangan sumber daya manusia, juga merupakan alat yang dapat digunakan untuk membentuk kepribadian anak, dan juga dapat digunakan sebagai wadah bagi anak untuk tumbuh dan berkembang. Pendidikan di SD harus memperhatikan kebutuhan anak yang berusia antara 6-12 tahun. Anak dalam kelompok usia 7-11 tahun menurut Piaget (2010) berada dalam perkembangan kemampuan intelektual/kognitifnya pada tingkatan operasional konkret. Mereka juga belum memahami konsep yang abstrak, yang mereka pedulikan adalah hal yang konkret. Salah satu muatan pelajaran yang menekankan hal yang konkret adalah IImu Pengetahuan Alam (IPA). Pembelajaran IPA diharapkan dapat membantu siswa untuk memahami fenomena-fenomena alam (Fitriyati, dkk, 2017). Pembelajaran IPA dengan memberikan pengalaman langsung dapat menumbuhkan cognitive thingking skill (keterampilan berpikir kognitif), psychomotor skills (keterampilan psikomotorik) dan social skills (keterampilan sosial) (Prabowo, 2015).

Selama satu tahun terakhir, Pandemi COVID-19 menjadi musibah yang luar biasa. Yang terjadi hampir di seluruh negara tanpa terkecuali, termasuk negara Indonesia. Pendemi ini menimbulkan dampak buruk pada seluruh tatanan kehidupan. Hal tersebut juga berdampak pada bidang pendidikan. Pemerintah dalam hal mencegah penyebaran penularan virus Covid-19 mengeluarkan Keputusan Menteri Kesehatan Republik Indonesia Nomor HK. 01.07 / MENKES / 413 / 2020 Tentang Pedoman Pencegahan dan Pengendalian Corona Virus Disease 2019 (COVID-19) . Hal yang serupa juga dilakukan oleh Menteri Pendidikan Nasional dengan mengeluarkan SE Nomor 36962 / MPK.A / HK / 2020, tentang Pembelajaran Secara Daring dan Bekerja dari Rumah Dalam Rangka Pencegahan Penyebaran Corona Virus Disease ( COVID-19).

Dalam situasi pandemi seperti ini guru dan peserta didik dituntut mempunyai kemampuan dalam mengoperasikan gadget berupa HP, Android, dan laptop sebagai alat utama pembelajaran daring. Guru sebagai pendidik harus tetap menyampaikan pembelajaran kepada peserta didik agar hak pembelajaran yang sebagaimana mestinya. Kondisi pembelajaran daring banyak mengalami kendala seperti terbatasnya jumlah gadget yang dimiliki peserta didik dengan satu Hand Phone untuk tiga anak dalam keluarga yang semuanya harus mengikuti pembelajaran daring yang sama. Tingkat ekonomi orang tua peserta didik yang masih kurang juga menyebabkan kesulitan dalam membeli kuota sebagai akses dalam pembelajaran daring. Kemampuan orang tua dan peseta didik yang terbatas dalam mengoperasikan Hand Phone dalam pembelajaran daring sehingga selama ini aplikasi yang termudah digunakan adalah Whatsapp Grup.

Pada kenyataannya pembelajaran daring belum maskimal, yang dikarenakan kondisi sarana dan prasarana serta kemampuan mengoperasikan aplikasi dari Guru dan peserta didik. Jumlah kepemilikan Hand Phone Android di kelas V SD Negeri 2 Pabuwaran adalah dari 33 peserta didik, yang memiliki secara pribadi berjumlah 15 anak selebihnya milik orang tua atau wali mereka. Guru sebagai pendidik juga masih kurang ahli dalam penggunaan aplikasi dalam pembelajaran daring. Sebagian besar guru hanya menggunakan aplikasi Whatsapp Grup dalam pelaksanaan pembelajaran dan mengerjakan soal-soal yang ada pada buku pendamping dengan sistem satu arah tanpa pendampingan guru. Peserta didik hanya didampingi orang tua sebagai sosok pengganti guru dalam menjelaskan konsep. Hal tersebut menjadikan hasil belajar peserta didik mengalami penurunan khususnya pada Muatan Pelajaran IPA pada Tema 1 Subtema 1 yaitu materi tentang "Organ Gerak Hewan". Terlihat dari hasil ratarata evaluasi yang dicapai peserta didik masih di bawah KKM yakni dari jumlah seluruh siswa yang lulus KKM hanya $45 \%$. Oleh karena, itu perlu dilakukan perbaikan pada 
proses pembelajaran sehingga hasil prestasi belajar peserta didik dapat tercapai sesuai dengan tujuan pembelajaran.

Salah satu upaya yang bisa dilakukan oleh guru selaku pendidik untuk meningkatkan hasil belajar peserta didik terutama pada muatan pelajaran IPA pada masa pandemi seperti sekarang ini yaitu dengan memanfaatkan aplikasi Zoom Meeting dengan media power point dan model pembelajaran Problem Based Learning. Faktor yang mempengaruhi prestasi hasil belajar peserta didik adalah minat dan motivasi belajar. Dengan adanya minat dan motivasi, peserta didik akan belajar lebih keras, ulet, tekun, dan memiliki konsentrasi penuh dalam proses pembalajaran daring. Dorongan motivasi belajar perlu ditingkatkan dalam upaya pembelajaran daring. Sehingga diharapkan mampu menuntaskan tujuan pembelajaran yang lebih maksimal

Model Problem Based Learning diharapkan dapat meningkatkan partisipasi dan prestasi belajar karena pada setiap tahapan pembelajaran, siswa diajak untuk aktif melakukan diskusi kelompok dan siswa akan belajar memecahkan masalah yang akan mengasah kemampuan siswa untuk ikut berperan dalam proses pembelajaran.Tan dalam Rusman (2011: 229) menyatakan bahwa Problem Based Learning atau pembelajaran berbasis masalah merupakan inovasi dalam pembelajaran, karena dalam PBL kemampuan berpikir siswa betul-betul dioptimalisasikan melalui proses kerja kelompok atau tim yang sistematis, sehingga siswa dapat memberdayakan, mengasah, menguji, dan mengembangkan kemampuan berpikirnya secara berkesinambungan. Margetson dalam Rusman (2011: 230) mengemukakan bahwa kurikulum PBL membantu untuk meningkatkan perkembangan keterampilan belajar sepanjang hayat dalam pola pikir yang terbuka, reflektif, kritis, dan belajar aktif.

Model Problem Based Learning (PBL) menekankan siswa untuk terlibat aktif dalam berbagai aktivitas pembelajaran, semua siswa dapat aktif dan merasakan langsung proses pembelajaran. Sehingga pembelajaran akan lebih bermakna dan menarik bagi siswa. Selain itu dengan menggunakan media dapat mendukung proses pembelajaran, maka perlu adanya penggunaan media pembelajaran yang mendukung. Penggunaan media pembelajaran adalah untuk memperjelas penyajian pesan dan informasi sehingga proses dan hasil pembelajaran dapat diperjelas dan ditingkatkan. Media pembelajaran juga dapat memandu perhatian siswa, yang dapat menimbulkan motivasi belajar sehingga mempengaruhi aktivitas dan hasil belajar. Penggunaan media yang kurang menarik dalam proses pembelajaran dapat membuat siswa merasa jenuh dan kurang aktif dalam menjawab pertanyaan yang diajukan guru kepada siswa.

\section{METODE}

Penelitian ini adalah penelitian tindakan kelas (Classroom Action Research) dengan menerapkan model pembelajaran Problem Based Learning (PBL). Menurut Kurt Lewin dalam Kunandar (2011: 42) penelitian tindakan kelas ini terdiri dari empat tahapan dasar yaitu perencanaan (planning), pelaksanaan (acting), pengamatan (observing) dan refleksi (reflecting). Analisis penelitian ini adalah analisis deskriptif kuantitafif kualitatif dimana dalam penelitian ini selain penyajian hasil berupa data maupun angka peneliti juga menentukan bagaimana cara pengolahan hasil penelitian yakni dengan membuat analisisnya dengan menerapkan model penelitian Problem Based Learning (PBL). Penelitian ini dilaksanakan pada peserta didik kelas V SD Negeri 2 Pabuwaran Tahun Pelajaran 2020/2021 selama dua siklus secara daring menggunakan aplikasi Zoom Meeting dengan dua pertemuan disetiap siklusnya. Siklus I dilaksanakan pada tanggal 21 dan 23 Juli 2020. Siklus II dilaksanakan pada tanggal 29 dan 31 Juli 2020. Teknik pengumpulan data yang dilakukan dengan observasi dan tes, baik pre test maupun post test. Observasi meliputi observasi keterlaksanaan model pembelajaran PBL, sikap peserta didik dan keterampilan. Untuk hasil belajar menggunakan tes melalui Google form. 


\section{HASIL DAN PEMBAHASAN}

Pada siklus I pembelajaran dilaksanakan selama dua pertemuan, setiap pertemuan diadakan pre test dan post test. Untuk mengetahui perkembangan peserta didik selama pembelajaran. Siklus I membahas materi tentang organ gerak manusia. Pembelajaran dengan model PBL dilaksanakan dengan 5 langkah PBL secara berurutan mulai dari menentukan orientasi peserta didik pada masalah, mengorganisasi peserta didik, membimbing penyelidikan, mengembangkan hasil, analisis dan evaluasi. Berikut ini adalah hasil belajar peserta didik pada siklus I yang bisa dilihat pada tabel berikut.

Tabel 1. Hasil Belajar Peserta Didik Siklus I

\begin{tabular}{ccccccccc}
\hline Siklus I & \multicolumn{3}{c}{ Pre test } & \multicolumn{3}{c}{ Post test } \\
& $\begin{array}{c}\text { Pesdik } \\
\text { tuntas }\end{array}$ & \multicolumn{2}{c}{$\begin{array}{c}\text { Pesdik } \\
\text { belum } \\
\text { tuntas }\end{array}$} & \multicolumn{2}{c}{$\begin{array}{c}\text { Pesdik } \\
\text { tuntas }\end{array}$} & $\begin{array}{c}\text { Pesdik } \\
\text { belum } \\
\text { tuntas }\end{array}$ \\
& Jml & $\%$ & Jml & $\%$ & Jml & $\%$ & Jml & $\%$ \\
\hline Pertemuan 1 & 19 & 58 & 14 & 42 & 25 & 75 & 8 & 25 \\
Pertemuan 2 & 24 & 73 & 9 & 28 & 27 & 82 & 6 & 18 \\
\hline
\end{tabular}

Berdasarkan tabel di atas maka terjadi peningkatan antara pre test dan post test pada pertemuan 1. Setiap individu peserta didik sudah mengalami peningkatan hasil belajarnya. Peserta didik mengalami peningkatan hasil belajar pada pertemuan 1. Ketuntasan klasikal juga mengalami peningkatan, pada pre test hanya terdapat 19 peserta didik yang sudah tuntas, tetapi pada post test bertambah menjadi 25 peserta didik yang sudah tuntas dengan Kriteria Ketuntasan Minimal (KKM) sebesar 70. Demikian juga pada pertemuan 2 jumlah peserta didik yang sudah tuntas KKM mengalami peningkatan. Pada pre test ada 24 peserta didik yang baru tuntas, sudah meningkat menjadi 27 peserta didik yang tuntas setelah melaksanakan post test. Perbandingan antara hasil post test pada pertemuan 1 dan pertemuan 2 juga terdapat perbedaan. Pada pertemuan 1 peserta didik yang sudah tuntas hanya ada 25 peserta didik, sedangkan pada pertemuan 2 sudah meningkat menjadi 27 peserta didik. Persentase ketuntasan klasikalnya meningkat, jika pertemuan 1 hanya $75 \%$ maka pada pertemuan 2 menjadi $82 \%$.

Berdasarkan refleksi pada siklus I maka diputuskan untuk melanjutkan ke siklus II dikarenakan belum mencapai ketuntasan klasikal yang diharapkan. Siklus II membahas materi tentang kelainan organ gerak manusia. Pembelajaran dengan model PBL dilaksanakan dengan 5 langkah PBL secara berurutan seperti siklus I. Berikut ini adalah hasil belajar peserta didik pada siklus II yang bisa dilihat pada tabel berikut.

Tabel 2. Hasil Belajar Peserta Didik Siklus II

\begin{tabular}{ccccccccc}
\hline & \multicolumn{3}{c}{ Pre test } & \multicolumn{3}{c}{ Post test } \\
Siklus II & $\begin{array}{c}\text { Pesdik } \\
\text { tuntas }\end{array}$ & \multicolumn{2}{c}{$\begin{array}{c}\text { Pesdik } \\
\text { belum } \\
\text { tuntas }\end{array}$} & \multicolumn{2}{c}{$\begin{array}{c}\text { Pesdik } \\
\text { tuntas }\end{array}$} & $\begin{array}{c}\text { Pesdik } \\
\text { belum } \\
\text { tuntas }\end{array}$ \\
& Jml & $\%$ & Jml & $\%$ & Jml & $\%$ & Jml & $\%$ \\
\hline Pertemuan 1 & 26 & 79 & 7 & 21 & 28 & 85 & 3 & 15 \\
Pertemuan 2 & 29 & 87 & 4 & 13 & 31 & 93 & 2 & 7 \\
\hline
\end{tabular}

Ketuntasan klasikal mengalami peningkatan, pada pre test hanya terdapat 26 anak yang sudah tuntas, tetapi pada post test bertambah menjadi 28 anak yang sudah tuntas dengan Kriteria Ketuntasan Minimal (KKM) sebesar 70. Demikian juga pada pertemuan 2 jumlah peserta didik yang sudah tuntas KKM mengalami peningkatan. 
Pada pre test ada 29 peserta didik yang baru tuntas, sudah meningkat menjadi 31 peserta didik yang tuntas setelah melaksanakan post test. Perbandingan antara hasil post test pada pertemuan 1 dan pertemuan 2 juga terdapat perbedaan. Pada pertemuan 1 peserta didik yang sudah tuntas hanya ada 26 peserta didik, sedangkan pada pertemuan 2 sudah meningkat menjadi 29 peserta didik. Persentase ketuntasan klasikalnya meningkat, jika pertemuan 1 hanya $85 \%$ maka pada pertemuan 2 menjadi $93 \%$.

Dari dua siklus yang sudah dilaksanakan selama 4 pertemuan dapat dipastikan bahwa model pembelajaran PBL dapat meningkatkan hasil belajar peserta didik pada mupel IPA Kelas V di SD Negeri 2 Pabuwaran. Hal ini sesuai dengan konsep atau teori yang diungkap oleh Hamruni (2011: 104) menyatakan bahwa pembelajaran berbasis masalah merupakan suatu model pembelajaran yang menggunakan masalah dunia nyata sebagai suatu konteks bagi siswa untuk belajar tentangcara berpikir kritis dan keterampilan pemecahan masalah, serta untuk memperoleh pengetahuan dan konsep yang esensial dari materi kuliah atau materi pelajaran. Peserta didik dapat memahami materi organ gerak manusia dengan tepat. Pada siklus II peserta didik juga dapat memcahkan masalah pada materi kelainan pada organ gerak sehingga pengetahuan yang dihasilkan dapat tertanam dengan permanen. Hasil penelitian ini juga sesuai dengan penelitian sebelumnya yang dilakukan oleh Reza Yuafian dan Suhandi Astuti (2020) yang membuktikan bahwa model pembelajaran Problem Based Learning (PBL) dapat meningkatkan hasil belajar peserta didik.

\section{SIMPULAN}

Penerapan model pembelajaran Problem Based Learning (PBL) dapat meningkatkan hasil belajar peserta didik Kelas $\mathrm{V}$ pada mupel IPA materi organ gerak manusia dan kelainan pada organ gerak manusia. pembelajaran menggunakan sistem daring dengan media power point dapat meningkatkan minat belajar siswa sehingga siswa lebih tertarik dalam proses pembelajaran. Selain itu peningkatan juga terjadi karena adanya kesan pembelajaran yang mendalam dari peserta didik terhadap materi yang diajarkan melalui setiap pemecahan masalah. Peserta didik akan selalu teringat akan materi yang diajarkan dikarenakan mereka dapat menyelesaikan masalah dengan mengambil solusi yang tepat. Berdasarkan hasil Penelitian Tindakan Kelas yang telah dilaksanakan selama dua siklus dalam upaya meningkatkan hasil belajar siswa IPA pada pokok bahasan organ gerak manusia dan kelainan organ gerak manusia dengan melalui model Problem Based Learning dapat ditarik kesimpulan Model pembelajaran Problem based learning dapat meningkatkan hasil belajar peserta didik.

\section{DAFTAR PUSTAKA}

Fitriyati, I, dkk. (2017). Pengembangan Perangkat Pembelajaran IPA untuk Meningkatkan Kemampuan Berpikir Tinggi dan Penalaran IImiah Siswa Sekolah Menengah Pertama. Jurnal Pembelajaran Sains, 4(1). 27-34.

Hamruni. (2011). Strategi Pembelajaran. Yogyakarta: Insan Madani

Keputusan Menteri Kesehatan Republik Indonesia.(2020). Pedoman Pencegahan dan Pengendalian Corona Virus Disease 2019 (COVID-19). HK.01.07/MENKES/413/2020

Kunandar. 2011. Langkah Mudah Penelitian Tindakan Kelas Sebagai Pengembang Profesi Guru. Jakarta: PT Raja Grafindo Persada.

Piaget, Jean, \& Barbel Inhelder, 2010. Psikologi Anak, Terj. Miftahul Jannah, Yogyakarta : Pustaka Pelajar 
Prabowo, S. A. (2015). The effectiveness of scientific based learning towards science process skill mastery of PGSD students. Jurnal Pendidikan IPA Indonesia, 4(1), 15-19.

Rusman. (2011). Model-Model Pembelajaran Mengembangkan Profesionalisme Guru. Jakarta: PT. Rajagrafindo Persada.

Yuafian, Reza dan Suhandi Astuti. (2020). Meningkatkan Hasil Belajar Siswa Menggunakan Model Pembelajaran Problem Based Learning (PBL). Jurnal Riset Pendidikan Dasar 03 (1), (2020) 17-24 